\title{
Diversity of Bacteria Contaminants in Tissues of Fish Cultured in Organic Waste-Fertilized Ponds: Health Implications
}

\author{
Joseph Addo Ampofo ${ }^{1, *}$ and George C. Clerk $^{2}$ \\ ${ }^{1}$ Water Research Institute, CSIR, P.O. Box M. 32, Accra, Ghana; ${ }^{2}$ University of Ghana, Legon, Ghana
}

\begin{abstract}
Bacterial populations contaminating various tissues of fish cultured in fish ponds fertilized with different organic wastes have been studied. Twenty-five genera of bacteria were identified as associated with the fish tissues. The identified bacteria included one genus of spiral and curved bacteria, one genus of Gram-negative aerobic rod, sixteen genera of Gram-negative facultative anaerobic rods, one Gram-negative anaerobic bacterium, three Gram-positive cocci, two endospore-forming rods, and one Actinomycete. The bacterial contaminants were isolated from all tissues of the cultured fish. Higher bacterial contamination was associated with the gills, gut and skin than the blood and muscle. Although Pseudomonas sp. was most abundant species in the organic waste fertilized ponds and was present in considerable quantities in the five fish tissues, Salmonella sp. was the most important contaminant of the gills, muscle and skin. The presence of high diversity of bacteria in the fish tissues presents health hazards to both consumers and fish farm workers. Handling and cleaning of the fish can result in contamination of hands of farm workers and through them to their family members and others. The digestive tract and intraperitoneal fluid of fish in this study showed high concentrations of pathogens, such as Salmonella in fish cultured in the organic waste fertilized ponds, but lower concentrations in fish cultured in nonfertilized pond. Public health must therefore be of prime concern when dealing with fish farming and its products in countries, such as Ghana, with less restriction on release of waste into water bodies, and the use of untreated wastewater for aquaculture.
\end{abstract}

Keywords: Organic-waste fertilized ponds, bacterial contaminants tissues.

\section{INTRODUCTION}

Application of fertilizers to ponds substantially increases fish yield but the increase in cost of commercial fertilizers makes the practice unprofitable. Interest has, therefore, been diverted to other sources of enrichment of the water, such as use of animal manure which causes algal blooms, provides feed for the fish, and also serves as a source of nutrients for microorganisms present in the water.

In Ghana poultry waste, blood waste, sewage, cow dung and pig dung are mostly used to fertilize fishponds and are considered superior to inorganic fertilizers in producing and maintaining desirable species of planktonic and benthic organisms in fresh and brackish water ponds [1]. Some farmers make regular application at three or four months intervals. Others depend on visual observation and add the waste according to the colour of the pond.

Many studies have shown that bacteria belonging mostly to the genera Aeromonas, Corynebacterium, Myxobacterium, Pseudomonas and Vibrio cause infectious diseases in fish $[2,3]$. Most infections begin on the mucus membranes. To initiate infection the bacteria must reach susceptible organ or adhere to the epithelial cells [2]. In certain diseases they remain localized at the mucosal surface and cause damage by liberating toxins. In most cases, however, infection is caused

*Address correspondence to these authors at the Water Research Institute, CSIR, P.O. Box M 32, Accra, Ghana; Tel: 233-21-779515; Fax: 233-21777170; E-mail: jaampofo@yahoo.com by the pathogen penetrating the epithelium and then growing in the sub-mucosa or spreading even further [3]. Successful invasion depends on the ability of the pathogen to outcompete the normal microflora for nutrients. Small breaks or lesions in the mucosal membrane also facilitate spread of pathogens [3].

The health of fish is dependent on the quality of the water. The presence of some obligate pathogens such as Aeromonas salmonicida or Renibacterium salmonarum in water is an indication of the presence of fish disease on a farm [4]. However the bacterial load in water per se does not relate to possible health hazard. Indeed majority are beneficial saprobes involved in the numerous re-cycling processes. Of much concern in fisheries is the contamination of fishes by faecal coliforms in polluted waters [4].

In every country where fish inspection programme exists, the load of faecal coliforms in farmed, feral or processed fish is evaluated to verify whether the harvest or product presents a health hazard or not $[5,6]$. Their presence in fish intended for human consumption may constitute a potential danger not only in causing disease, but also because of the possible transfer of antibiotic resistance from aquatic bacteria to human infecting bacteria from non-aquatic sources [7]. Escherichia coli, the predominant species of the faecal coliforms, has been found in the intestinal tract of fish [8], on the gills, in the muscles and on the skin [9], when sewage water has been used to rear fish. Salle [10] reported that the most heavily contaminated parts are the intestines and the skin. Presence of E. coli in water or food indicates the possible 
presence of causative organisms of many gastro-intestinal diseases $[11,12]$. This study was therefore undertaken to investigate the diversity of bacteria pathogens in tissues of fish that are grown in ponds that receive fertilizers from various organic sources in Ghana and their health implications to the fish and human.

\section{MATERIALS AND METHOD}

Fish farms used in this study were ponds being used for commercial purposes, and which retained water throughout the year. They were drainable and had well conditioned dykes and each was fertilized with only one type of fertilizer. They included cow manure-fertilized pond, poultry manurefertilized pond, pig manure-fertilized pond, and, blood manure-fertilized pond. Each pond was stocked with tilapia. Fish from River Volta, a non-fertilized pond was used as control.

Cast net was used to collect fish samples from the various ponds. Five live tilapias were randomly selected from the catch at each sampling time.

Sterile cotton bud was used to take a swap from the surface of the fish immediately upon collection from the pond. The cotton bud was placed immediately in $5 \mathrm{ml}$ sterile peptone water in sterile plastic applicator (Rayon), labeled and kept at $4^{\circ} \mathrm{C}$ and transported to the laboratory.

In the laboratory each fish was rinsed with de-ionized water and the surface of the fish decontaminated by dipping it in ethyl alcohol and lightly flames. The fish was aseptically dissected and parts of the gills, gut and muscle were taken for analysis. Blood sample was also collected using a sterile syringe. Each tissue was homogenized separately in a blender in sterile phosphate buffered saline PBS of $\mathrm{pH} 7.2$ to achieve a $10 \% \mathrm{w} / \mathrm{v}$ suspension of fish.

Tests were carried out on each isolate following the procedures described by Bailey and Scott [13], Prescott et al. [14] and Cheesbrough [15] to enable identification to the generic and species levels with the aid of the Bergey's Manual of Determinative Bacteriology [16].

\section{SELECTIVE CULTURE OF BACTERIAL ISOLATES}

Forty isolates were randomly selected from plates of each culture. Isolation and subsequent identification of bacteria were done using Trypticase Soy Agar (TSA), standard biochemical tests $[14,15]$ and the API 20E Kit [17]. Strains of E. coli (1) 0 sera (Denka Seiken No 24506, Tokyo, Japan) were used to type for enterotoxigenic, enteropathogenic, enteroinvasive, anetroaggregative and enetrohaemorrhagic $E$. coli. Strains of Salmonella and Shigella were serologically typed with specific Salmonella and Shigella antisera (O grouping) (Remel Inc, USA). Each colony was identified to the generic level and the frequency of occurrence of each genus in the selected 40 colonies determined. In cases where tissue parts could not produce a total of 40 colonies, all isolates were identified and the frequency based on the total number of colonies.

\section{STATISTICAL ANALYSIS}

The Statgraphics Plus for Windows 4.0 [18] was employed to test for significant differences between the various means of bacteria genera from the various tissues of fish. The data for number of isolated bacterial genera were subjected to analysis of variance (ANOVA), where $\mathrm{P}<0.05$ was judged indicative of a significant difference. Where the ANOVA revealed significant differences, Duncan's multiple range test [19] was applied in order to characterize and quantify the differences between tissue bacterial flora populations.

\section{RESULTS AND DISCUSSION}

Tilapia caught from the various culture systems fertilized with different sources of organic wastes and those caught from non-fertilized pond were found to harbor bacteria belonging to twenty-five genera of bacteria, in various tissues of the fish, but at different magnitudes (Table 1). The bacteria isolated from the various tissues of the fish from both the fertilized and unfertilized ponds included Actinobacillus sp., Aeromonas sp., Bacillus sp., Bacteroides sp., Campylobacter sp., Citrobacter sp., i sp., Corynebacterium sp., Edwardsiella sp., Enterobacter sp., Escherichia sp., Flavobacterium sp., Hafnia sp., Klebsiella sp., Micrococcus sp., Pasteurella sp., Proteus sp., Pseudomonas sp., Salmonella sp., Serratia sp., Shigella sp., Staphylococcus sp., Streptococcus sp., Vibrio sp. and Yersinia sp.

Bacterial genera isolated from the blood were between $12-16$, and $17-21$ genera in the muscle of fish. Between $24-25$ genera were isolated from the skin, 25 genera from the gills and $10-23$ genera from the gut.

The study indicated that certain species seemed to be associated more with certain tissues than with others. For example Edwardsiella sp., Pasteurella sp. and Salmonella sp. were abundant in the muscle of fish, while the blood contained higher presence of Corynebacterium sp., Flavobacterium sp. and Pseudomonas sp. For the gills, gut and skin, the respective dominant genera were Bacillus sp., Pseudomonas sp., and, Streptococcus sp. and Vibrio sp., respectively.

Analysis of variance determination showed significant difference at $95.0 \%$ confidence level between the means for the muscle, blood, gut, gill and skin of the fish. Duncan's multiple comparison determination showed homogeneity between the means for the blood and muscles, and, among the means for the gill, gut and skin.

With fish cultured in poultry manure-fertilized ponds the data showed the presence of $17-21$ genera in the muscles, 11 - 20 in the blood flora, 24 - 25 in the gills and in the skin flora and 19 - 23 genera in the gut.

Fish cultured in pig manure-fertilized ponds contained between 17 - 24 genera isolated from the muscle, while $11-$ 15 genera were isolated from the blood. Between $24-25$ genera were isolated from the gills, $11-13$ genera from the gut and between 24 to 25 genera from the skin.

Fish cultured in blood waste-fertilized pond had15, 14 and 22 genera isolated from the muscle, blood and gut, respectively.

The dominant species of the muscle flora were Pasteurella sp., Escherichia sp. and Salmonella sp. The dominant species in the blood flora was Micrococcus sp., followed by Campylobacter sp. and then by Aeromonas sp. Salmonella sp. was the predominant species in the gill flora 
Table 1. Bacteria Species Diversity of Fish Cultured in Organic Fertilized Ponds

\begin{tabular}{|c|c|c|c|c|}
\hline \multirow{3}{*}{$\begin{array}{c}\text { Fish } \\
\text { Part/Tissue }\end{array}$} & \multicolumn{4}{|c|}{ Bacteria Pathogens Isolated From } \\
\hline & \multicolumn{3}{|c|}{ Type of Fertilizer Applied to Pond } & \multirow{2}{*}{$\begin{array}{c}\text { Open System / No Fertili- } \\
\text { zation }\end{array}$} \\
\hline & Poultry Manure & Pig Manure & Blood Meal & \\
\hline Blood & $\begin{array}{c}\text { Corynebacterium } \\
\text { Flavobacterium } \\
\text { Pseudomonas } \\
\text { Micrococcus }\end{array}$ & $\begin{array}{c}\text { Corynebacterium } \\
\text { Pseudomonas Micrococcus }\end{array}$ & $\begin{array}{c}\text { Aeromonas } \\
\text { Campylobacter } \\
\text { Flavobacterium } \\
\text { Micrococcus }\end{array}$ & $\begin{array}{c}\text { Hafnia } \\
\text { Pseudomonas } \\
\text { Micrococcus } \\
\text { Yersinia }\end{array}$ \\
\hline Gills & $\begin{array}{c}\text { Actinobacillus } \\
\text { Bacillus } \\
\text { Pseudomonas } \\
\text { Salmonella } \\
\text { Shigella }\end{array}$ & $\begin{array}{c}\text { Bacillus } \\
\text { Clostridium } \\
\text { Klebsiella } \\
\text { Proteus } \\
\text { Salmonella } \\
\text { Staphylococcus }\end{array}$ & $\begin{array}{c}\text { Bacillus } \\
\text { Salmonella } \\
\text { Serratia } \\
\text { Vibrio }\end{array}$ & $\begin{array}{c}\text { Bacillus } \\
\text { Enterobacter } \\
\text { Escherichia } \\
\text { Flavobacterium } \\
\text { Pseudomonas }\end{array}$ \\
\hline Gut & $\begin{array}{c}\text { Enterobacter } \\
\text { Escherichia } \\
\text { Pseudomonas } \\
\text { Micrococcus } \\
\text { Salmonella } \\
\text { Shigella }\end{array}$ & $\begin{array}{c}\text { Citrobacter } \\
\text { Clostridium } \\
\text { Klebsiella } \\
\text { Streptococcus }\end{array}$ & $\begin{array}{c}\text { Bacteroides } \\
\text { Micrococcus } \\
\text { Proteus } \\
\text { Staphylococcus }\end{array}$ & $\begin{array}{c}\text { Bacillus } \\
\text { Edwardsiella } \\
\text { Escherichia } \\
\text { Micrococcus } \\
\text { Pseudomonas }\end{array}$ \\
\hline Muscle & $\begin{array}{c}\text { Bacillus Edwardsiella } \\
\text { Pasteurella } \\
\text { Pseudomonas } \\
\text { Salmonella }\end{array}$ & $\begin{array}{c}\text { Edwardsiella } \\
\text { Pasteurella } \\
\text { Pseudomonas } \\
\text { Salmonella }\end{array}$ & $\begin{array}{c}\text { Edwardsiella } \\
\text { Escherichia } \\
\text { Pasteurella } \\
\text { Salmonella }\end{array}$ & $\begin{array}{c}\text { Edwardsiella } \\
\text { Pasteurella } \\
\text { Salmonella }\end{array}$ \\
\hline Skin & $\begin{array}{c}\text { Bacillus } \\
\text { Pasteurella } \\
\text { Salmonella } \\
\text { Shigella } \\
\text { Streptococcus } \\
\text { Yersinia }\end{array}$ & $\begin{array}{c}\text { Bacillus } \\
\text { Proteus } \\
\text { Pseudomonas } \\
\text { Streptococcus }\end{array}$ & $\begin{array}{c}\text { Bacillus } \\
\text { Flavobacterium } \\
\text { Salmonella } \\
\text { Shigella } \\
\text { Staphylococcus } \\
\text { Streptococcus }\end{array}$ & $\begin{array}{c}\text { Bacillus } \\
\text { Citrobacter } \\
\text { Edwardsiella } \\
\text { Enterobacter } \\
\text { Escherichia } \\
\text { Pseudomonas } \\
\text { Salmonella } \\
\text { Streptococcus }\end{array}$ \\
\hline
\end{tabular}

followed by Bacillus sp. and by Vibrio sp. Micrococcus sp. was found to be the predominant species in the gut. Salmonella sp. dominated the flora of the skin, followed by Bacillus sp., and then Flavobacterium sp.

Analysis of variance determination showed significant difference at $95.0 \%$ confidence level between the means of the values for the blood, gill, gut, muscle and skin flora. Duncan's multiple comparison determination showed homogeneity between the means of the blood and muscles, and between the gill, gut and skin.

This study has indicated that fish cultured in various types of organic waste fertilized ponds are susceptible to infection with pathogenic bacteria. Fish from the nonfertilized pond had bacteria detected in the different tissues, but at relatively low numbers. Salmonella spp. was most commonly identified with most of the tissues, and was de- tected in the muscles, on the gills and skin. The occurrence of disease is a complex interaction between host species, pathogens and the environment [20]. Most aquacultural practices that favour disease occurrence include high stocking densities which increase stress in the stocks, intensive feeding which provides abundant substrate for microbial growth and sub-optimal environment of inadequate water exchange $[7,9]$. Disease outbreaks would thus be relatively less common in the non-fertilized pond as it has less stressful environments, even though the pathogens and host species may be present.

Frazier [12] stated that species of Clostridium, Flavobacterium, Micrococcus, Proteus and Pseudomonas are the major spoilage bacteria at near freezing temperatures. Raj and Liston [20] found that some pathogenic and potentially pathogenic microorganisms including E. coli, Staphylococ- 
cus and some anaerobes survived when uncooked and precooked fish foods were stored at freezing temperatures. Studies by Roberts [2] showed that bacteria belonging mostly to the genera Aeromonas, Corynebacterium, Pseudomonas and Vibrio cause infectious diseases in fish. The presence of these twenty-five genera in the fish is, therefore, a threat to the fish industry as fish, which do not succumb to the attack may still be subjected to spoilage.

The presence of the coliform group of bacteria, mainly Citrobacter, Enterobacter, Escherichia and Klebsiella in fish and fish products presents a health hazard to humans [4, 6, 22]. Allen and Hepher [23] have stated that most of the epidemics attributed to wastewater sources are from raw sewage gaining access to food eaten directly by man, or from contamination of water supply systems by untreated sewage. Olayemi et al. [7] have reported that the presence of faecal coliform in fish intended for human consumption may constitute a potential danger not only in causing disease, but also because of the possible transfer of antibiotic resistance from aquatic bacteria to human infecting bacteria from nonaquatic sources. Some human pathogens such as Aeromonas, Escherichia, Klebsiella, Pseudomonas, Salmonella and Vibrio have been found to survive and multiply in the gut, mucus and tissues of fish and thus render fish a potential vector of human disease over long periods [24]. All these pathogens have been identified to be present in the tissues of fish that were cultured in the organic waste-fertilized ponds in this study. Public health must therefore be of prime concern when dealing with fish farming and its products in countries with less restriction on release of waste into water bodies, and in use of untreated wastewater for aquaculture. The digestive tract and intraperitoneal fluid of fish in this study showed concentrations of pathogens. Handling and cleaning of such contaminated fish can result in contamination of the hands of farm workers and through them to their family members and others.

The similar pattern of variation in the water and fish tissues of the population of bacterial flora is a possible indication that bacterial biomass forms an important part of the diet in Oreochromis niloticus and that gut microflora [25], whether it be autochthonous or allochthonous or both, could possibly play an important role in the nutrition of the fish. A higher bacterial load in the gut of fish has been observed than in the surrounding waters [25-27]. This study thus confirms the suggestion that fish selectively feed on detrital particles with high numbers of bacterial biomass per unit weight $[28,29]$, thus concentrating bacteria in their foreguts at levels higher than those in the surrounding environment. Henebry et al. [25] observed increased bacterial population in the midgut of silver carp and suggested that bacterial populations may increase in the midgut before being ultimately digested, thereby providing high quality protein for the fish. Sera and Ishida [30] observed increased total heterotrophic bacteria count from $10^{4}$ to $10^{8}$ cells per gram in the intestine of red sea bream snapper (Pargus major) 16 hours after ingestion of food. Many species of bacteria that are normally considered saprophytic, including species of Bacillus, Micrococcus and Proteus have been isolated from infections of tropical fish [31]. However, since in the present study separate counts for the flora in the foregut, midgut and hindgut were not done, it is difficult to determine whether bacteria serve directly as source of protein for O. niloticus or indirectly by synthesizing vitamins required by the fish. Most probably they perform both functions, and their relatively high density in the gut of fish is of important survival value.

It is suspected that the organic wastes improve considerably the nutrients levels in the ponds, a situation that will increase the population of bacteria present in the ponds [7, 9]. This is ideal for the growth of the fish, as food will be in abundance. However, with conditions where pathogenic bacteria are introduced into the ponds with the wastes, the risk of transfer of diseases to the fish and humans is high [20]. The use of the organic wastes to fertilize the ponds is costsaving and recommended if some form of treatment can be given to the wastes to eliminate the bacterial pathogens. One form of such reduced cost of treatment can be by solar treatment.

The safety of products for consumption is prime concern from the point of view of managing of the fish culture systems, as well as ensuring public health [32]. Official regulatory bodies in many countries specify maximum permissible concentrations of toxic substances or the number of harmful bacteria that a product may contain, in order to ensure that unfit or unwholesome food does not reach the consumer. Even though not usually covered by regulations, unattractive appearance and tainting of products affect their marketability [33]. Water quality and culture practices play important roles in determining product quality. In Ghana most of the fish consumed is bought directly from the fishermen and do not pass through any health-safety checks. Instituting and ensuring fish inspection programmes to regulate the quality of fresh fish from the farm or in the market in Ghana would be a safeguard to protect the health of consumers.

\section{ACKNOWLEDGEMENTS}

This investigation received financial support from the Government of Ghana. The authors would like to thank the Director-General of the Council for Scientific and Industrial Research of Ghana, the Director of the Water Research Institute, the Head of Environmental Biology and Health Division and the Head of Department of Botany, University of Ghana for their assistance. They are also grateful to the personnel of the Public Health and Reference Laboratory, Korle $\mathrm{Bu}$ Teaching Hospital, Ghana. The cooperation and efforts of the staff of the Microbiology Section of the Water Research Institute are acknowledged.

\section{REFERENCES}

[1] Pillay TVR. Sources and utilization of water. Water and waste water use. In: Rosenthal H, Volker H, Kamstra A, Eds. Aquaculture and the Environment. Halsted Press: an Imprint of John Wiley and Sons, Inc. New York Toronto 1992

[2] Roberts RT. Neoplasia of fishes. Fish Pathology, $1^{\text {st }}$ ed. London: Bailliere Tindall 1978.

[3] Kabata Z. Parasites and diseases of fish cultured in the tropics. London and Philadelphia Taylor and Francis Ltd. 1985.

[4] Caldreich EE, Clarke NA. Bacterial pollution indicators in the intestinal tract of freshwater fish. J Appl Microbiol 1966; 41: 42937.

[5] Blackwood CM. Microbiological quality of fishery products - role and environment, Canada. Fisheries Inspection Branch. Can Inst Food Sci Technol J 1978; 1: A42-9. 
[6] Fapohunda AO, MacMillan KW, Marshall DL, Waites WM. Growth of selected cross-contaminating bacterial pathogens on beef and fish at 15 and $35^{\circ} \mathrm{C}$. J Food Protect 1994; 57: 337-40.

[7] Olayemi AB, Adebayo O, Ojo AO. Microbial flora of six freshwater fish species from Asa River, Ilorin, Nigeria. Rev Biol Trop 1991; 39: 165-7.

[8] Newman JT, Consenza BJ, Buck JD. Aerobic microflora of the bluefish (Pomatomus saltatrix) intestine. J Fish Res Board Can 1972; 29: 333-6.

[9] Ogbondeminu FS. The occurrence and distribution of enteric bacteria in fish and water of tropical aquaculture ponds in Nigeria. $\mathrm{J}$ Aquac Trop 1993; 8: 61-6.

[10] Salle AJ. Fundamental principles of bacteriology, $5^{\text {th }}$ ed. New York McGraw-HillBook Co. 1964.

[11] DHSS. The bacteriological Examination of Drinking Water Supplies 1982. London, HMSO Public Health Laboratory Service, 1991.

[12] Frazier WCC. Food Microbiology. Bombay, India Tata McGrawHill Publishing Co. Ltd. 1958.

[13] Finegold SM, Baron EJ. Methods for identification of etiologic agents of infectious disease. In: Bailey and Scott's Diagnostic Microbiology. 7th ed, C.V Mosby Company. Toronto, Princeton: St. Louis, Missouri 1986.

[14] Prescott LM, Harley JP, Klein DA. Microbiology New-York McGraw-Hill Companies, Inc. 2005.

[15] Cheesbrough M. Medical Laboratory Manual for Tropical Countries. Microbiology. Tropical Health Technology \& ButterworthHeinemann 1994; Vol. II.

[16] Holt JG, Greig NR, Sneath PHA, Williams ST. Bergey's Manual of Determinative Bacteriology $9^{\text {th }}$ ed. Williams \& Williams. Maryland, USA Baltimore 1994.

[17] Bio Merieux SA. Analytical Profile Index 20E. Marcy-l'Etoile, Lyon - France 1992.

[18] Statgraphics Plus for Windows version 4.0 Manugistics Inc. Rockville, MD, USA $4^{\text {th }}$ October 1999: Available from answer@manu.com

[19] Duncan D. Multiple range tests and multiple F tests. Biometrics 1995; $11(1): 1-5$.
[20] Herbst S, Fayzieva D, Kistemann T. Risk factor analysis of diarrhoeal diseases in the Aral Sea area (Khorezm, Uzbekistan). Int J Environ Health Res 2008; 18(5): 305-21.

[21] Raj H, Liston J. Survival of bacteria of Public Health significance in frozen seafoods. Food Technol 1961; 6: 421-33.

[22] van DUIJN JC. Diseases of fishes, $3^{\text {rd }}$ ed. Butterworth Co. Ltd. London 1973.

[23] Allen GH, Busch RA, Morton AW. Preliminary bacteriological studies on wastewater- fertilized marine fishponds. Humboldt Bay, California Bay, California. In: Advances in Aquaculture Fishing News Books, Oxford, England 1979; pp. 492-8.

[24] Allen GH, Hepher B. Recycling of wastes through aquaculture and constraints to wider application. In: Advances in aquaculture Pillay TVR and Dill WA, Eds. Oxford, Fishing News Books, England 1969; pp. 478-87.

[25] Henebry MS, Gordon RW, Buck DH. Bacterial populations in the gut of the silver carp (Hypophthalmichthys molitrix) Prog Fish Cult 1988; 50: 86-92.

[26] Mary PP. Studies on the gastrointestinal microflora of the mullet Liza dussumeiei (Valenciennes) Ph.D. Thesis Cas in Marine Biol Annamalai University 1977.

[27] Shiranee P, Natarajan P, Dherendran R. The role of gut and sediment bacterial flora in the nutrition of cultured pearl spot (Etroplus saratensis, Bloch). Israel J Aquac - Bamidgeh 1993; 45(2): 45-58.

[28] Odum WE. The ecological significance of fine particles selection by the striped mullet, Mugil cephalus. Limnol Oceanogr 1968; 13: 92-8.

[29] Moriarty DJW. Quantitative studies on the bacteria and algae in the food of the mullet Mugil cephalus $\mathrm{L}$ and the prawn Metapenaeus bennettae (Tack and Dall). J Exp Mar Biol Ecol 1976; 22: 131-43.

[30] Sera H, Ishida Y. Bacterial flora in the digestive tracts of marine fish. II. Changes of bacterial flora with time lapse after ingestion of diet. Bull Jpn Soc Sci-Fish 1972; 38: 633.

[31] Almeida LJ, da Silva, Freitas YM. Microorganisms from some tropical fish diseases. J Fish Res Board Can 1968; 25: 197-201.

[32] Schotissek C, Naylor ER. Fish farming and influenza pandemis. Nature 1988; 33: 215.

[33] Bullock GL. Pseudomonadales as fish pathogens. Dev Indust Microbiol 1964; 5: 101-8.

Received: October 15, 2009

Revised: February 08, 2010

Accepted: February 16, 2010

(C) Ampofo and Clerk; Licensee Bentham Open.

This is an open access article licensed under the terms of the Creative Commons Attribution Non-Commercial License (http: //creativecommons.org/licenses/by-nc/3.0/) which permits unrestricted, non-commercial use, distribution and reproduction in any medium, provided the work is properly cited. 